\title{
Investigating Self-Regulated Learning Differences Based on Gender, Scholarship, and Student's Housing
}

\author{
Nurdian Susilowati ${ }^{1}$, Sari Lestari ${ }^{2}$, Dela Yuniarsih ${ }^{3}$, Deviana Hardining Maharani ${ }^{4}$ \\ 1,2,3,4 Universitas Negeri Semarang, Indonesia
}

\begin{tabular}{l}
\hline Article Info \\
\hline Article history: \\
Received: 06 November 2019; \\
Accepted: 28 February 2020; \\
Published: 01 March 2020.
\end{tabular}

Keywords:

Gender; Scholarship; Selfregulated Learning; Student's housing.

\begin{abstract}
This study aims to determine the differences students' self-regulated learning (SRL) based on gender, scholarship, and student's housing. Referring to Roscoe, our sample of the study is 36 students by using purposive sampling technique.. Analysis of the data are quantitative descriptive and hypothesis testing using independent sample t-test. The results showed that there is no significant difference in selfregulated learning based on gender. Self-regulated learning of female is higher than male students. Based on scholarships, there is no significant difference in self-regulated learning but students as scholarship recipients have higher self-regulated learning.Then, there is no significant difference based on house hold but students who live at home have highest self-regulated learning than students who live in boarding schools and boarding house. This research gives implication theoretically and practically. The finding proves that students who have self-regulated learning higher than others is due to good habit and intrinsic motivation. Thus; this research suggestsfor the university to establish good environment for students to develop themselves.

Abstrak

Penelitian ini bertujuan untuk mengetahui perbedaan self-regulated learning (SRL) siswa berdasarkan jenis kelamin, beasiswa, dan tempat tinggal. Mengacu pada Roscoe, sampel penelitian kami adalah 36 siswa dengan menggunakan teknik purposive sampling. Analisis data adalah deskriptif kuantitatif dan pengujian hipotesis menggunakan independent sample t-test. Hasil penelitian menunjukkan bahwa tidak ada perbedaan yang signifikan kemandirian belajar berdasarkan jenis kelamin. Kemandirian belajar perempuan lebih tinggi daripada siswa laki-laki. Berdasarkan beasiswa, tidak ada perbedaan yang signifikan tetapi siswa sebagai penerima beasiswa memiliki kemandirian belajar yang lebih tinggi. Kemudian, tidak ada perbedaan signifikan berdasarkan tempat tinggi tetapi siswa yang tinggal di rumah memiliki kemandirian belajar tertinggi daripada siswa yang tinggal di sekolah asrama dan asrama umum. Penelitian ini memberikan implikasi secara teoritis dan praktis. Temuan membuktikan bahwa siswa yang memiliki kemandirian belajat lebih tinggi daripada yang lain adalah karena kebiasaan yang baik dan motivasi intrinsik. Jadi; Penelitian ini menyarankan agar universitas membangun lingkungan yang baik bagi siswa untuk mengembangkan diri.
\end{abstract}

\section{How to Cite:}

Susilowati, N.,Lestari, S., Yuniarsi, D., \& Maharani, D.H. (2020). Investigating Self-Regulated Learning Differences Based on Gender, Scholarship, and Student's Housing. Jurnal Pendidikan Ekonomi \& Bisnis, 8(1), 25-33. https://doi.org/10.21009/JPEB.008.1.3 


\section{INTRODUCTION}

University students are considered as the highest student's status in Indonesia education system. It requires students to be more independent and take full responsibility for their own learning processes. In line with the vision Faculty of Economics Universitas Negeri Semarang (UNNES), students are expected to become competent graduates, have academic and / or professional skills, in the fields of economics, and business, and economic education in dealing with the development of science and technology and the world of work, honest with ethics, and have social responsibility.

Students who do not have the responsibility, independence and motivation in learning means that they do not have self-regulation. Self-regulation according to Zimmerman (2012), is not an ability in academics, but rather how to regulate the learning process of individuals independently through planning, setting, and achieving goals. Self-regulation has three aspects, they are;: 1) metacognition, where the students do planning, setting goals, and evaluating assignments, 2) motivational aspect, which is when individuals have high confidence and enthusiasm in doing their tasks, 3) behaviour is an attempt to regulate themselves, select, and utilize the environment and create an environment that supports learning activities.

Students who use self-regulated learning tend to be able to organize and control themselves in the learning process independently, planned, organized, and achieve the goals. Each student is also required to be able to find the right strategy to facilitate the learning process. Students who learn well by self-regulated learning can know themselves and how they learn. Self-regulated learning is one of the constructive theories that makes students able to achieve learning goals. A student must have the ability to organize themselves. If students are faced with a complex problem, they will know how to solve that problem.

Every individual is not the same own uniqueness. These individual differences also cause differences in learning behaviour among students. Learning difficulties are not always due to low intelligence (mental disorders), but can also be caused by non-intelligence factors. Thus; a high IQ may not guarantee success in learning (Ahmadi et al, 2004). There are some factors that influence learning, they are; internal factors, such as physical health, and psychological factors (intelligence, attention, talent, interest, motivation, readiness, and maturity).

Self-regulated learning combines many things, such as motivation, knowledge, and selfdiscipline behaviour. Self-regulated learning is a process in which students play an active role in learning to achieve learning goals. In more detail, self-regulated learning is a learning process in which students play an active role in metacognitive, motivational, and behaviour for the achievement of learning goals (Zimmerman \& Pons, 2001). They regulate their own metacognitive, motivational, and behaviour in a way that supports the process of understanding or comprehension.

There are some factors that influence self-regulated learning, they are; personal, behavioural and environmental factors (Zimmerman, 1989). There were studies in Indonesia on this theme conducted by Ahmad (2010). He found that there was not any difference in self-regulated learning between male and female students. In contrast to the results of research conducted by Permata Sari et al (2015). The results showed that there were differences in self-regulated learning of male and female students. Women have higher self-regulated learning than men.

Besides gender, the differences in the level of self-regulated learning are also determined by the behaviour of scholarship recipients. As a result of research conducted by Prakoso (2016) that there are differences in the level of self-regulated learning between students receiving Bidikmisi (type of scholarship) and those who do not receive Bidikmisi. Bidikmisi recipient students tend to have higher levels of self-regulated learning. It is because scholarship recipients have their own academic demands that must be met.

When students have been able to organize themselves well, the next step taken is to create a learning environment to support the learning process. The home environment greatly determines the level of self-regulated learning. The level of self-regulated learning for students who live at home, in the boarding house and in the boarding school will definitely be different. Discipline and atmosphere in boarding schools are very different from home and boarding house.

Student who live in the boarding school are accustomed to living independently with various rules that must be obeyed. Unlike the case with students who are in theboarding house with habits 
that are built themselves.

Based on the description above, it is known that there are differences in the results of previous studies. Furthermore, previous research only focused on one variable, such as differences in selfregulated learning by gender and recipient of scholarships even though the variables regarding the household need to be examined. This encourages researchers to examine the differences in selfregulated learning in various aspects, they are; gender, household and scholarships that are studied together.

The formulation of the problem in this study is how the differences in self-regulated learning between students who live at home, boarding house and boarding school. Then, the difference between self-regulated learning between male students and female students. Next, the difference between selfregulated learning between scholarship recipients and non-scholarship recipients.

The contribution to be achieved from this research is knowledge insight about differences in self-regulated learning or control seen from several categories including gender, scholarships and house hold. For students, it is hoped that this research can improve self-management for the better and optimize learning. For higher education institutes, teachers, and parents, the results of this study can produce a picture of the dynamics of student learning thus; it can be used as a basis for motivating students to optimize their learning process.

Albert Bandura in 1991 developed the Social Cognitive Theory based on the concept that learning is influenced by cognitive, behavioural and environmental factors. This contrasts with traditional psychological theory which emphasizes learning through direct experience. Bandura (1989) argues that the observational learning process is governed by four main aspects they are; attention, retention, reproduction and motivation.

Attention is the process by which people selectively observe and extract information from ongoing activities. Retention involves the process of changing information in the form of rules and conceptions then storing information into memory. Reproduction is the act of observing behaviour. The last aspect is motivation which encourages students to pay attention, practice and retention.

Social cognitive theory emphasizes that learning is not a simple imitation process and humans are managers of their own behaviour. Based on these ideas, several important concepts in learning were born, they are; the concept of human agency, self-regulated, and self-efficacy.

\section{METHOD}

This study used descriptive method by using comparative technique approach between students with scholarship and non-scholarship. Refering to Roscoe (1975) stated that sample size larger than 30 and smaller than 500 are appropriate for the studies. This study used 36 students in Faculty of Economics UNNES.

This study uses a purposive sampling method which is one of the non-random sampling techniques where we determined the sampling with specific characteristics to answer the research problem. In respect to gender, of 36 students consist of 18 female and 18 male students. In addition, in terms of scholarship holder, it classified 18 scholarship recipients and 18 non-scholarship recipients. For the house hold category, there are 12 students who live in their own homes, 12 students who live in fostered houses/boarding school, and 12 students who live in public boarding houses.

Data analysis techniques is quantitative descriptive and independent sample t-test. Quantitative descriptive analysis shows the percentage results regarding the ability of self-regulated learning. Data analysis was performed in advance through data collection based on the Motivated Strategies for Learning Questionnaire (MSLQ) instrument to determine student self-regulated learning (SRL). The data collection instrument uses the Osgood scale which provides seven alternative answers. Data retrieval of research results is carried out by giving a scale of one to seven. The data generated is nominal scale data. By using anchors of " $1=$ "very incompatible" to " 7 =very compatible".

Based on the results, $R$ table is sought at a significance value of 0.05 with a 2 -tailed test and the amount of data $(n)=36$ thus; the $r$ table is 0.283 . Items declared valid if the correlation value is more than 0.283. Thus; there are 3 invalid items, they are; statement no 6 which is an indicator of task value, number 8 which is an indicator of control believe, and number 32 which is an indicator of peer learning. These three items were eliminated due to analysis. 
Reliability Test is intended to measure the consistency of statement items in showing the same results. The reliability test method used in this study is Cronbach's Alpha. Statement items are said to be reliable if the Cronbach's Alpha value is greater than 0.6.

Table 1. Reliability Statistics

\begin{tabular}{cc}
\hline $\begin{array}{c}\text { Cronbach's } \\
\text { Alpha }\end{array}$ & N of Items \\
\hline 0.921 & 32 \\
\hline \multicolumn{2}{c}{ Source: data processed, 2019}
\end{tabular}

Based on the above output it is known that the Cronbach's Alpha value is 0.921. This shows the statement items used reliably. Furthermore according to Uma Sekaran (2003), the Cronbach's Alpha value which reached 0.8 can be said to be good reliability.

\section{RESULTS AND DISCUSSION}

Data analysis techniques in this study used quantitative descriptive analysis techniques by showing the percentage results regarding the ability of self-regulated learning. Based on the calculation, the frequency distribution table is obtained as follows.

Table 2. Frequency Distribution

\begin{tabular}{lllrr}
\hline No. & \multicolumn{1}{c}{ Interval } & \multicolumn{1}{c}{ Category } & Frequency & \multicolumn{2}{c}{ Percentage } \\
\hline 1. & $108-135$ & Low & 11 & $31 \%$ \\
2. & $136-163$ & Medium & 16 & $44 \%$ \\
3. & $164-191$ & High & 9 & $25 \%$ \\
& Total & & 36 & $100 \%$ \\
\hline
\end{tabular}

Source: Data processed, 2019

Based on table 4.1 it can be seen that overall, 31\% of respondents have low self-regulated learning. As many as $44 \%$ of students have moderate self-regulated learning and $25 \%$ of students have a high category of self-regulated learning. This shows that the majority of students can adequately regulate themselves by using self-regulated learning strategies in achieving learning objectives.

Table 3. Self-regulated Learning by Respondent Category

\begin{tabular}{llcl}
\hline No. & Respondent & Mean & Category \\
\hline 1. & Gender & & \\
& Female & 150.22 & Medium \\
& Male & 141.39 & Medium \\
2. & Scholarship & 151.11 & Medium \\
& Recipient & 140.50 & Medium \\
& Non Recipient & & \\
3. & House Hold & 151,25 & Medium \\
& Home & 150,83 & Medium \\
& Boarding School & 135,33 & Low \\
\hline
\end{tabular}

Source: Data processed, 2019

Based on table 4.2 , it can be found that all respondents have an average level of self-regulated learning in the medium category, except for students who live in public boarding houses the average level of self-regulated learning falls into the low category.

Based on results, it is known that the number of valid data for male students is 18 people and women are 18 people. It means that nothing is missing. The second output is the Independent Sample Test with the F-test to determine whether the data variants are the same. If the variance is the same, 
then the t-test uses the output equal variances assumed but if the variant is different it uses the not variant equal variant.

The significance value of the F- test is 0.097 or greater than 0.05 , it is concluded that the two variants are the same. Therefore; the use of the t-test uses the assumed equal variance. From the output, the value of $t$ is -1.274 . In this case, the hypothesis made is a directed hypothesis thus; it uses sig 1 tailed. Furthermore, the distribution table $t$ is sought at $\mathrm{df}=34(\mathrm{n}-2)$ and 1 tailed 0.05 is 1.691 or t count is smaller than t table. Thus; $\mathrm{H} 1$ is supported thus; it can be concluded that there is no significant difference in self-regulated learning between female students and male students.

In respect to gender, there was small gap between women with an average of 150.22 and men with an average of 141.39. This average result at the same time answers the second hypothesis that self-regulated learning of female students is better than male students. From a different-test that is using the significance test, the results obtained are sig. 1 tailed was 0.105 . This calculation is the result of sig 2 tailed divided by $2(0.211 / 2)$. Significance value of 0.105 is greater than 0.05 , hence H1 is accepted, it means that there is no significant difference in self-regulated learning between male and female students.

Next, about scholarship recipients. The significance value of the F-test is 0.846 or greater than 0.05 , it is concluded that the two variants are the same. Therefore; the use of the t-test uses the assumed equal variance. From the output obtained $t$ count is 1.547. In this case, the hypothesis made is a directed hypothesis thus; it uses sig 1 tailed. Furthermore, the distribution table $t$ is sought at df $=34(\mathrm{n}-2)$ and 1 tailed 0.05 is 1.691 or $\mathrm{t}$ count is smaller than t table. Thus; H3 is supported thus; it can be concluded that there is not any difference between self-regulated learning of scholarship recipients and students who do not receive scholarships.

This is because the difference in the level of self-regulated learning based on scholarship is only hence are; in students with an average scholarship (mean) level of self-regulated learning of 151.11 and men with an average of 140.50. These results answer that H4 is that self-regulated scholarship recipients are better than non-scholarship recipient students.

From a different-test that is using the significance test, the results obtained are sig. 1 tailed was 0.065 . This calculation is the result of sig 2 tailed divided by $2(0.131 / 2)$. The significance value of 0.065 is greater than 0.05 , so H3 is accepted, it means that there is not any difference in self-regulated learning between scholarship recipients and students who have not received significant scholarships.

Testing the differences between three or more independent sample groups using one way ANOVA as follows. Based on the results, it is known that the number of valid data for students who live in their homes is 12 people, students who live in boarding school are 12 people, and students who are live in boarding house are 12 people. It means that there is no missing data.

From the calculated F-value is known 2.426. By using a 95\% confidence level df 1 (number of data groups-1) or 3-1 $=2$ and df 2 (n-3) or 36-3 = 33, the results obtained for the F-table are 3,285. The test criteria were decided to support $\mathrm{H} 5$ because the F-count was not greater than the F-table. It means that there is no significant difference in the level of self-regulated learning between students who live at home, Islamic boarding schools, and public boarding.

However, in the descriptive table, it showed that the average self-regulated learning for students who live in their own homes is 151.25 , for students who live in boarding schools and the like is 150.83, and for students who live in public boarding house is 135,333 . These results reject Hypothesis 6 which states that self-regulated learning of students who live in a boarding school is better than students who live at home or in a public boarding house.

\section{DISCUSSION}

Based on the results of the study, it was found that there were no significant differences in selfregulated learning between female students and male students. This shows that gender differences have no effect on self-control in learning or self-regulated learning. These findings support the research of Ruminta et al (2017) who found that both male and female students have and show the same self-learning characteristics on all four dimensions are cognition, motivation/affect, behavior and context. The findings of this study state that there is no significant difference in self-regulated learning between male and female students. As said by (Bidjerano and Dai, 2007) the gender differences found 
may be a function of the stereotypical belief that women are expected to be conscientious, organized, and skilful in managing their learning environment. But these stereotypes can be lost if those who believe in them can be controlled (Valiante and Pajares, 1999). Psychologically, there is not a single theory that says that men are smarter than women. The results of intelligence tests show that women also get the same score as men.

The results of this study also contradict the results of research by Zimmerman (2002) which suggests that female students have a greater general tendency in the use of self-regulated learning strategies than male students. Specifically, female students reported more keeping records and monitoring as well as setting and planning goals (goal setting and planning). In contrast, these findings indicate that there are not any differences in self-regulated learning in male and female students, thus; $\mathrm{H} 1$ research is supported. There are differences in self-regulated learning between men and women due to stereotypes that convince people of the different academic abilities between men and women and not because of gender itself.

Based on the results of data analysis, there is no significant difference in self-regulated learning among scholarship recipients and non scholarship recipients. This indicates that the acceptance of scholarships does not have an impact on students' self-regulated learning not because they have confidence in themselves to do assignments, do not yet have learning goals and the importance of assignments, and have feelings of anxiety about assignments but there are other factors that influence self-regulated learning they are; internal factors and external factors (Woolfolk, 2009). Internal factors include psychological factors such as intelligence, attitudes, interests, talents and physiological factors (student's condition) and external factors include learning environment, parenting style, approach style used by students in learning, assignments, relations between students and lecturers and learning facilities.

Independent-test results of self-regulated learning sample tests between scholarship recipients and non-scholarship recipients in the results obtained that indicate that there is no significant difference between self-regulated learning recipient students and non-scholarship recipients. Thus; the hypothesis proposed in this study was accepted, they are; there was not any difference in the level of self-regulated learning of students who received and did not receive scholarships.

The absence of a significant difference shows that the level of self-regulated learning of scholarship recipients and non-scholarship recipients is almost the same. Judging from the mean level of self-regulated learning scholarship recipients are higher. This happens because the recipient student and not the recipient of the scholarship both have responsibilities to the parents and the scholarship provider. Hence, they have the motivation and independent learning strategythe psychological aspects of students who did not receive a scholarship means tuition is borne by parents so they tend to have high learning motivation. While scholarship recipients tend to have good learning strategies and responsibilities to scholarship providers thus they have higher self-regulated learning.

Based on research conducted by Hasanah, et.al (2019), it was found that there was a positive relationship between self-regulated learning and Grade Point Average (GPA). The higher the selfregulated learning the higher the student GPA. This supports the result that scholarship recipients have higher self-regulated learning even though the difference is not significant with self-regulated learning students who are not scholarship recipients. Scholarship recipients have high self-regulated learning in order to achieve a high GPA as me.

\section{CONCLUSIONS AND SUGGESTION}

The results showed that there are no significant differences in self-regulated learning based on gender, scholarship, and students's housing. But at the same time, the result of this research indicate that female, students as scholarship recipients and student who live at home have higher level of self-regulated learning. This research provides implication theoretically and practically. The results show that students who have self-regulated learning higher than others is due to good habit and intrinsic motivation as indicator of self-regulated learning.

Thus this research suggests to university to establish good environment for students to develop themselves.For students, they are expected to increase internal motivation to achieve learning goals.It is better to direct campus activities and programs to support the improvement of 
students' self-regulated learning. The researchers also provide some suggestions for further researchers, it is expected to increase the number of study samples to show a more accurate level of self-regulated learning.

\section{REFERENCES}

Adicondro, N., dan Purnamasari. (2010). Efikasi Diri, Dukungan Sosial Keluarga, dan Self Regulated Learning Pada Mahasiswa Kelas VIII. Jurnal Humanitas (Vol. 8, No.1).

Ahmad, R. (2010). Pengelolaan Pembelajaran. Jakarta: RinekaCipta

Ahmadi et.al. (2004). Psikologi Belajar (edisirevisi). Jakarta: Rineka Cipta

Asizah.,dan Hendrati. (2013). Intensitas Komunikasi Antara Anak dengan Orang Tua dan Self Regulation pada Remaja Pesantren. Jurnal Psikologi Indonesia, (Vol.2 No.2). 90-98.

Boekaerts, Monique. Pintrich, Paul R. \&Zeidner, Moshe. (2000). Handbook of Self-Regulation. California, USA: Academic Press

Bezzina, Frank H. (2001). Investigating Gender Differences in Mathematics Performance and in SelfRegulated https://www.emeraldinsight.com/doi/abs/10.1108/02610151011074407.

Learning.

Bidjerano, T., \& Dai, D. Y. (2007). The Relationship Between the Big-Five Model of Personality and Self-Regulated Learning Strategies. Learning and Individual Differences, (17). 69-81.

Clearly, Timothy J and .Pegy P.C. (2009). Self-Regulation, Motivation, and Math Achievement in Middle School: Variations Across Grade Level and Math Context. https://www.ncbi.nlm.nih.gov/pubmed/19712778

Gunarsa. (2004). Psikologis Praktis Anak, Remaja dan Keluarga. Jakarta: BPK Gunung Mulia.

Hasanah, Uswatun, et.al. (2019). Hubungan Regulasi Diri Dalam Belajar dengan Prestasi Belajar pada Mahasiswa Angkatan 2016 Fakulats Kedokteran Universitas Malahayati. Psyche Jurnal Psikologi,(Vol 1. No 1).

Hermanto et.al. (2018). The Role of Self Regulation in Moderating The Environmental Influences to The Learning Outcome. Journal of Primary Education, (Vol.7 No.1).

Hughes et.al. 2018. The Effects of Self-Regulated Learning and Cognitive Load on Beginning to Watch and Completing Video Lectures at a Cyber-University. https://www.emeraldinsight.com/doi/abs/10.1108/ITSE-03-2018-0018

Kenny, M.E. (1997). The Extent and Function of Parental Attachment Among First Year College Students. Journal of Youth and Adolescence, (Vol. 16). 17-29.

Lisnawati. (2013). Studi Perbedaan tingkat Self-regulated Learning Ditinjau dari Spiritual WellBeing pada Siswa di Sekolah Berbasis Pesantren dan Non Pesantren. Jurnal Psikologi Integratif,(Vol.1 No. 1), 124-134.

Matthe et al. (2009). Early Gender Differences in Self-Regulation and Academic Chievement. https://www.researchgate.net

Montalvo, F. T, dan Torres, M. (2004). Self-regulated Learning: Current and Future Directions. Journal Educational Psychology,(Vol.2 No. 1). 1-34.

Mulyani. (2013). Hubungan Antara Manajemen Waktu Dengan Self Regulated Learning Pada Mahasiswa. Educational Psychology Journal, (Vol. 2 No. 1).

Ormrod, Jeanne. Ellis. (2008). Psikologi Pendidikan: Membantu Siswa Tumbuh dan Berkembang. 6th Edition. Transalator: Dra. Wahyu Indianti, M.Si., Dra. Eva Septiani, M.Si., Airin Y. Saleh, M.Psi., dan Dra. Puji Lestari, M.Psi. Jakarta: Erlangga.

Permatasari, A., Nirwana, N., Ahmad, R. (2015). Regulasi Diri Belajar dan Locus of Control Siswa 
Ditinjau dari Jenis Kelamin dan Latar Belakang Budaya. Jurnal konselor, (Vol. 4, No.1). http://ejournal.unp.ac.id/index.php/konselor.

Pintrich, P., Smith, D., Garcia, T., \& McKeachie, W.J. (1991). A Manual of the Use of the Motivated Strategies for Learning Questionnaire (MSLQ). Ann Arbor: The University of Michigan

Pons.,\& Martinez (2009). Test of A Model of Parental Inducement of Academic Self Regulation. The Journal of Experimental Education,(Vol. 64 No. 3). 213-227.

Praindekoso, Singgih Dian. (2016). Perbedaan Self-Regulated Learning padaMahasiswaBidikmisi dan Non-Bidikmisi Fakultas Ilmu Pendidikan UNNES. skripsi. UNNES

Riduwan dan Kuncoro. (2011). Cara Menggunakan dan Memaknai Analisis Jalur Path Analysis. Bandung: Alfabeta.

Roscoe, J. T. (1975). Fundamental Research Statistics for the Behavioural Sciences. (2nd ed.) New York: Holt Rinehart \& Winston.

Ruminta, Triatri Sri, and Mularsih Heni. (2017). Perbedaan Regulasi Diri Belajar Pada Siswa Sekolah Dasar Kelas VI Ditinjau Dari Jenis Kelamin. Jurnal Muara Ilmu Sosial, Humaniora, dan Seni 2:286-94.

Russell, Douglass, and Racquel Warner. (2017). Motivational Intermediaries of Self-Regulation Among university students https://www.emeraldinsight.com/doi/abs/10.1108/JARHE-08-2015-0062.

Saputra et.al. (2018). Perbedaan Self-Regulated Learning Siswa Sekolah Menengah Kejuruan Berdasarkan Jenis Kelamin. Jurnal Kajian Bimbingan dan Konseling, (Vol 3. No.3).

Sekaran, Uma. (2003). Research Methods For Business: A Skill Building Aproach. New York-USA: John Wiley and Sons, Inc.

Sepang, Monique Grace Katouce. (2014). Perbedaan Self-Regulated Learning Antara Mahasiswa yang Tinggal Dengan Orang Tua dan yang Tidak Tinggal Dengan Orang Tua (Indekos). Thesis. Universitas Kristen Satya Wacana Salatiga.

Susanto, H. (2006). Mengembangkan Kemampuan Self-regulation untuk Meningkatkan Keberhasilan Akademik Siswa. Jurnal Pendidikan Penabur, 07. 64-71.

Stoten, David William. (2013). The Extended Project Qualification: An Example of Self-Regulated Learning in Sixth Form Colleges. https://www.emeraldinsight.com/doi/abs/10.1108/IJLLS06-2013-0035

Tang, Min and Heinz Neber.(2008). Motivation and Self-Regulated Science Learning in HighAchieving Students: Differences Related to Nation, Gender, and Grade-Level. https://www.tandfonline.com/doi/abs/10.1080/13598130802503959

Ulfah. (2016). Hubungan Antara Task Value Dengan Self-Regulation of Learning Pada Mahasiswa Yang Tinggal Di Pondok Pesantren Sindangsari Al-Jawami. http://pustaka.unpad.ac.id

Valiante, G. dan Pajares, F. (1999). The Inviting/Disinviting Index: Instrument Validation and Relation to Motiation and Achievement. Journal of Invitational Theory and Practice, (Vol 6, No 1).

Wolters, C.A., Pintrich, P.R., dan Karabenick, S.A. (2003). Assesing Academic Self Regulated Learning. Conference on Indicators of Positive Development: Child Trends.

Woolfolk, Anita. (2009). "Educational Psychology Active Learning Edition". 10th Edition, 2nd Part. Yogyakarta: Pustaka Pelajar.

Zimmerman, B. J. (1989). Developing Self-fullfilling cycles of Academic Regulation: An Analysis of Exemplary Instructional Models. In D. H. Schunk \& B. J. Zimmerman (Eds.), Selfregulated learning: From teaching to self-reflective practice (pp. 1-19). New York, NY: Guilford Press.

Zimmerman, B.J., \& Martinez-Pons, M. (2001). Student Differences in Self-Regulated Learning: 
Relating Grade, Sex, and Giftedness to Self Efficiacy and Strategy Use. Journal of Educational Psychology,(Vol. 82 No. 1). 51-59.

Zimmerman, B. J. (2012). Goal Setting: A Key Proactive Source of Academic Self-Regulation. In Schunk, D.H. \& Zimmerman, B.J. (Eds.), Motivation and Self-regulated learning Theory, Research, and Applications. New York, NY: Routledge Taylor \& Francis Group. 